\title{
Problems Encountered in Adapting the Industrial Policy to the New Economic Realities
}

\author{
${ }^{*}{ }^{*}$ Elena V. Volkodavova, ${ }^{2}$ Alexander P. Zhabin, ${ }^{3}$ Tatyana Goryacheva, ${ }^{4}$ Olesya Tomazova \\ ${ }^{1,2}$ Doctor of Economics, Professor, Samara State University of Economics, Russian Federation \\ ${ }^{3}$ Doctor of Economics, Professor, Saratov Yuri Gagarin State Technical University, Russian Federation \\ ${ }^{4} \mathrm{PhD}$ (Economics), Associate Professor, Samara State Technical University, Russian Federation \\ E-mail: ${ }^{* 1}$ vev.sseu@gmail.com, ${ }^{2}$ zhabin@sseu.ru, ${ }^{3}$ tvgsgtu@rambler.ru, ${ }^{4}$ ovtom@mail.ru
}

Received: $10^{\text {th }}$ January 2018, Accepted: $22^{\text {nd }}$ January 2018, Published: $2^{\text {th }}$ February 2018

\begin{abstract}
The purpose of the study is to analyze industrial policies that have been practiced in various parts of the world over the past several decades, as well as the principles and structural components (e.g. scope, agents, priorityoriented approaches, incentives and outcomes) of a multi-level industrial policy adapted to the new economic realities. The study is focused on the levels at which the industrial policy is shaped and implemented from an individual manufacturing company level to the national one. The paper proves that it is critical that the national industrial development strategy is based on import substitution (the national industry cannot develop without manufacturing high-tech products with high added value). The authors analyze Russia's industrial policy regulations and look into the history of creating the legal framework for the national industrial policy. The methods proposed for implementing the industrial policy use a systematic approach, the concept of market agents' rational behavior and comparative analysis. Along with traditional methods of industrial policy making, structural and foresight methods are discussed. Special attention is given to import substitution, a type of economic strategy and industrial policy which is new to Russia. Import substitution is expected to result in higher competitiveness of Russian manufacturers and their products, which will be achieved by stimulating modernization of manufacturing processes, enhancing productivity and launching new competitive products with relatively high added value. The main conclusion drawn from the study is that the industrial policy should be shaped and implemented on four levels. For the individual company level, this approach suggests using a model that relates resources to outcomes. The article gives a detailed description of this model's structural elements and their relations. Considering that the management process tends to change, and changes in both international and domestic environment necessitate altering structural components or relations between them, or introducing new components, a list of issues to be discussed is proposed.
\end{abstract}

\author{
Keywords: Industrial Policy, Import \\ Substitution, Regulations, Principles, Structural Compo \\ nents.
}

\section{Introduction}

Over the past years different institutes of economics have been increasingly involved in discussing problems that can be encountered by the Russian federal government while it is trying to make a sensible industrial policy. The reason is that financial stabilization of institutional transformations for different property is seen by the government as the priority task to no avail, whereas other tasks, such as making manufacturing industry more efficient or producing material values, do not get enough attention. The economy model that combines high prices for primary resources with strong government regulation of business activities and GDP (Gross Domestic Product) growth had reached its limits long before the advent of the crisis (the crisis only makes the problem worse). In view of that, the priority in making the national industrial policy is to combine measures to increase international competitiveness with renewal of local industry resources for different regions and providing institutional support to regions that have advantages in the development of priority manufacturing industries.

Manufacturing is, of course, the main sector in which priority areas for Russia's economy development should be determined. This is why a decision was made to keep studying the industrial policy-making process on all levels - from individual manufacturers to the national scale. These days, however, most industries are experiencing stagnation. The main reasons for that include the absence of a concerted national priority development strategy for cutting-edge technologies (a strategy that is based on the latest developments) and the long-experienced absence of codified industrial policy. At the same time, the latest trends in the economy development show that all industrial policy makers are interested in making and implementing it in the best possible way. 
The economic situation may get even worse now that the industrial policy suddenly became dominated by import substitution. The need for import substitution became especially obvious with appearance of new realities in the country's economic life (events in Ukraine, economic sanctions from a number of countries etc.) There is a danger, however, that the policy of import substitution may boil down to the use of knock down assembly lines also known in Russia as "screwdriver production lines" (Polovinkin \& Fomichev, 2014) [1]. What are the distinctive features of the new economic realities? Among the factors that influence those norms are not only economic relations, but also the political situation, new geographical realities, and changes caused by migration processes. Most leading countries of the world have obviously moved onto a new path of growth and development. Apart from a change in the pace of development, moving onto a new path involves launching new products in new geographic areas. Developing countries have also taken a new course in their development which has become faster. Those countries are now bringing cardinal changes in the global economy's structure. In the past, the economic development of most countries was largely influenced by the American market; these days, though, Asian economies play a much more significant role in determining the world economy development trends.

\section{Brief Literature Review}

Reviewing articles recently published by authors outside of Russia shows that many scholars from other countries discuss industrial policy issues. R. H. Wade (2010) [2] explained "why the mainstream prescription for the role of government in development is questionable". The article describes some key points about the nature of industrial policy in East Asia and about the general rationale for a certain kind of industrial policy even where state capacity is relatively weak". Later R.H. Wade (2012) [3] spelled out key ideas behind the consensus - in particular, its rejection of industrial policy. Nathan \& Overman (2013) [4] considered the possibility that some horizontal industrial policy objectives may be better served by specifically targeting particular places or from decentralized design or delivery. S.G. Lazzarini (2015) [5] proposed a model which expands the potential determinants of competitive advantage into the context of governmental intervention. P. Aghion et al. (2015) [6] showed, using a comprehensive dataset of all medium and large enterprises in China between 1998 and 2007, that "industrial policies allocated to competitive sectors or that foster competition in a sector increase productivity growth". P. Intarakumnerd (2016) [7] analyzed modern industrial policy practice in the context of development. Yiyun \& Zhu (2017) [8] investigated the trends and determinants of geographic concentration and industrial specialization in China. Changes also affect markets for certain products, such a synergy resources or information technologies. Small and medium enterprises that actively implement innovations have more impact on those markets than large power and IT corporations (The report of the Civic Chamber of the
Russian Federation on industrial policy and innovations for 2007) [9]. Nowadays the direction of research and technology advancement is becoming less and less predictable; digital technologies are spreading more and more rapidly in all spheres of the material world, more and more often new technologies are commercialized and transferred from peace-time industries to military industries and not the other way around as was the case until recently (Medvedev, 2015) [10].

Development priorities of the civil society and business community are changing not only in economy, science and technology, but also in humanitarian, social and cultural spheres. Thus, there is a sharp rise in the degree to which our life is virtualized, in the quality of human capital, which is more and more often viewed as a resource for the real sector of economy, and in competitiveness of the national economy.

"Competing for human capital which is becoming the key factor in carrying out any country's strategic tasks" (Medvedev, 2015) [10] determines the country's competitiveness and social development trends. The new social state we are currently building aims for customization of public services (mostly in health and education sectors) which results in state-of-the-art technologies replacing humans not only in the manufacturing, but also in the service sector. One of the first economists to analyze this phenomenon was the famous M. El-Erian (2010) [11] who noticed that the conventional economy model would not come back into use after the crisis of 2008-2009; instead, the crisis would be followed by a "long and complicated period of forming a new model" (Medvedev, 2015) [10]. There are, however, a number of problems in industry development, which cannot be effectively solved by legislative acts alone, whether those acts are passed by the federal government or local authorities. Here are a few examples of such problems: changing the manufacturing industry structure, innovation breakthroughs, and developing the national complex of manufacturing industry and market infrastructure so that distinctive features of particular geographic regions are taken into account. Problems of that sort can only be solved if on all levels of the management hierarchy there is an effective mechanism to make and implement an integrated coordinated industrial policy. It is worth looking in detail at the components of such mechanism, but before we do that, let us look at the specific traits of the current legislation that regulates the industrial policy.

\section{Legislation and Regulations supporting the Industrial Policy}

Many economists, politicians and scholars still "deny the practicality of having a national industrial policy in place" (Kazantsev, 2003) [12] and the need to regulate it with legislative acts, despite the fact that the issue has a long history and it has been proved more than once that one can benefit from legal acts regulating the industrial policy. Building a regulatory framework for the national industrial policy, technical regulation and pricing took a long time, and even after passing The Industrial Policy 
Act of 31.12.2014 [13], which sets up the principles of government support for participants of import substitution programs, this framework is still far from being perfect. Here are some of the legislative initiatives that have undoubtedly proved to be successful: introduction of set forms for investment contracts (the forms are approved by the government for certain industries for a ten-year periods) under which businesses will be given tax advantages, attractive rental rates for state property and other benefits; a guarantee that their income tax burden related to the return on investments under the contract will not increase; lower rates for goods, work and services whose prices are subject to state regulation; providing financial support through loans, subsidies and budget allocations within the framework of state programs; a new mechanism of providing financial assistance through industrial development funds set up by the federal government or regional authorities.

Although it is only a framework document in terms of its content and structure, and its provisions need to be concretized by passing further regulatory acts, the Act favors Russia's industry development and makes more likely the advent of competitive manufacturers of highquality domestic products that will be exported outside Russia. Let us have a closer look on the prospects and benefits that manufacturers have enjoyed since the Act was passed:

1. The Act clearly defines the main objectives of the government's industrial policy as follows: "to create an internationally competitive high-technologybased industrial complex capable of ensuring a smooth transition of the national economy from the resourcebased type to the type where the emphasis is put on innovation-driven growth; to increase the production volume for goods with high percentage of added value; to protect exporters of those products and guarantee independence of manufacturing composite lead time" (Federal Law No. 488 known as Russia's Industrial Policy Act, 2014) [14].

2. Apart from regulating activities of manufacturers, federal and municipal authorities, the Act introduces the concept of manufacturer support infrastructure. It is for the first time that this concept has been introduced as a statutory provision; it covers businesses, non-profit companies, state investment funds set up to invest in industrial development, and mixed capital funds.

3 In accordance with the Act, manufacturers of goods are not the only ones who can rely on the state for support; others include producers of electric power, suppliers of natural gas and water (both running water and hot steam) and sewage removal and treatment services.

4. The Act serves as a framework for creating the national industrial database to allow continuous monitoring of industrial growth. The database will contain information on the current status and prospects of the industrial complex, on companies and organizations operating in particular industries, as well as plans and opportunities for manufacturing important types of products.

5. Under the Act, the authorities of constituent regions of the Russian Federation are entitled to pass their own legal acts and regulations of local significance, use the regional budget to finance laying out of research and development programs, and lay the groundwork and set requirements for industrial facilities (Tolkachev, 2014) [15] located on territories governed by them.

6. The Act allows using various forms of financial support for the industrial complex development for example, shifting subsidies from the federal budget to privileged regions so that regional authorities could distribute the sums received from the federal government as they think appropriate.

7. The Act introduces the concept of an investment contract - a new form of legal relationship between the government and investing companies that are willing to launch new commercial products. Under the investment contract, authorities shall provide congenial investment climate and tax abatements for investors.

Currently, laying out an import substitution program based on the Act is seen as a priority in the industrial development. The next priority area for development will be manufacturing high-tech products with high added value.

\section{Methodology}

The industrial policy constructed by the RF government runs into a number of issues which need further attention. First of all, it is necessary to adapt the methods and principles on which the policy is based to the new economic realities. That is the reason why this study focuses on mechanisms and tools the governments of other countries used to shape their industrial policies and the results they achieved, as well as the prospects of using their experience in modern Russia. Another important issue is the strategy of forming the principles, instruments and methods of adapting Russia's industrial policy to new realities.

The following principles and concepts form the basis of the study:

- The holistic analysis principles on which the authors relied to cover a wide variety of aspects of shaping the industrial policy in the Russian Federation

- Guidelines for the systematic approach that was applied to shaping Russia's industrial policy on macro-, meso- and microeconomic levels. The authors study relations along the line "government - industry - manufacturer" in solving particular problems faced by those who shape the industrial policy and assess the effectiveness of decisions made

- The concept of market agents' rational behavior, that can be relied on in drawing conclusions on the competitiveness and manufacturing cost of import-substituting products in the Russian Federation 
- Comparative analysis based on which conclusions can be drawn on how successfully the problems of implementing the industrial policy are solved in Russia (comparison is drawn between Russia's and other countries' experience).

Manufacturing industry of the RF serves as an experimental base for the study.

The study went through the following phases: first, the methods that could be used for shaping and implementing on different levels the RF's industrial policy adapted for the growing economic integration were described by T. V. Goryacheva $(2012 ; 2013)[16$, 17]; then the theory justifying the chosen methods of structuring the process-oriented management of shaping and implementing the multi-level industrial policy was described in the works by A. P. Zhabin, E. V. Volkodavova \& T. V. Goryacheva (2015) [18], E. V. Volkodavova \& A. P. Zhabin (2016) [19], E. V. Volkodavova, A. P. Zhabin \& G. I. Yakovlev (2016) [20]. After imposing sectoral economic sanctions on Russian manufacturers in 2014, the focus of researchers' attention shifted towards finding solutions to two problems: how to increase economic safety and how to make Russian manufacturers more independent by using various means such as import substitution. Therefore, the paper looks closely at various industrial policy types and how they are implemented in different countries, the role of various agents in shaping the industrial policy of a particular manufacturing company, and principles of shaping and implementing a multi-level industrial policy.

Empirical Data. The Specifics of Different Industrial Policy Types

Throughout the text of the Act there is abundant evidence of the fact that the government supports import substitution, but what does the term mean?

Import substitution is "a type of the state's economic strategy and industrial policy which is aimed protecting the domestic manufacturer by refusing to import commercial products and replacing them with domestic ones" (Polovinkin \& Fomichev, 2014) [1]. Import substitution is expected to result in domestic manufacturers becoming more competitive. High competitiveness will be achieved by stimulating technological modernization, productivity enhancement, launching new competitive products with relatively high added value.

V. K. Fal'tsman (2015) [21] analyzed the problem of import substitution for the most import capacious sectors of the Russian economy. R.V. Kashbrasiev \& A. G. Stepin (2016) [22] worked out a typology of Russian regions based on their import activity and analyzed the main types from an import-substitution perspective.
A successful effective import substitution program should suggest a gradual transition to manufacturing science-intensive, high-technology products, boost production development, improve the quality of products and manufacturing processes, foster innovations.

In our opinion, an import substitution program should have the following goals:

(1) Guarantee Russia's National Safety

(2) Achieve technological self-sufficiency in critical sectors by creating "growth points" for leading manufacturers and stimulating dynamic development of priority sectors

(3) Ensure a positive export surplus

(4) Do the groundwork for a gradual transition from the policy of import substitution to a strategic industrial policy.

"After pursuing the import substitution policy for several years (maybe 5 to 7 years), industrial production in the RF may increase by 10 or even 15 percent" (Polovinkin \& Fomichev, 2014) [1]. Of course, it is impossible to stop using imported products altogether, but it is necessary to launch the process of import substitution - either with the government's money or with investors' funds. By implementing the input substitution program we will be able to ensure the national downstream industry growth. A number of experts, e.g. Kazantsev (2003) [12], Andrianov (2012) [23], Afanasyev (2007) [24], Babynina (2010) [25], McMillan (2008) [26] and Okimoto (1991) [27], describe industrial policies using some alternatives to import substitution. Those alternative industrial policies are listed in Table 1. They include internal market orientation (protects the internal market and relies on economic selfsufficiency / import substitution), export orientation (priority is given to exporting certain types of products) and strategic industrial policy, which limits the use of natural resources - both non-renewable (oil, ores, minerals etc.) and renewable ones. 
Helix Vol. 8(2): 3237-3247

Tab. 1: Industrial Policies of Other Countries

\begin{tabular}{|c|c|c|c|c|c|c|}
\hline State & Industrial policy type & Priority industries & Implementation mechanism & Instrument & Problems & Results \\
\hline $\begin{array}{l}\text { Korea in } \\
1960 \mathrm{~s}- \\
80 \mathrm{~s}\end{array}$ & Export orientation & $\begin{array}{l}\text { were identified, but the list } \\
\text { was continually revised }\end{array}$ & Investing in priority industries & $\begin{array}{l}\text { Tax abatements, establishing chaebols } \\
\text { (financial industrial groups), restraint of } \\
\text { competition }\end{array}$ & $\begin{array}{l}\text { Chaebols } \\
\text { threatened } \\
\text { economic } \\
\text { growth }\end{array}$ & $\begin{array}{l}\text { Concentration of economic power. } 30 \\
\text { conglomerates in the processing } \\
\text { industrycover } 1 / 3 \text { of the market and account } \\
\text { for } 1 / 2 \text { of exports }\end{array}$ \\
\hline $\begin{array}{l}\text { China in } \\
1960 \mathrm{~s}- \\
70 \mathrm{~s}\end{array}$ & Internal market orientation & \multirow[t]{2}{*}{ were identified } & \multirow[t]{2}{*}{$\begin{array}{l}\text { Government investing in } \\
\text { priority industries }\end{array}$} & \multirow[t]{2}{*}{ Tax abatements and holidays } & \multirow[t]{2}{*}{$\begin{array}{l}\text { Uneven } \\
\text { economic } \\
\text { growth }\end{array}$} & \multirow[t]{2}{*}{$\begin{array}{l}\text { The country had all commercial categories } \\
\text { mentioned in the UN classification, which } \\
\text { brought up to } 50 \% \text { of its GDP }\end{array}$} \\
\hline $\begin{array}{l}\text { China in } \\
1980 \mathrm{~s}- \\
90 \mathrm{~s}\end{array}$ & Export orientation & & & & & \\
\hline $\begin{array}{l}\text { India in } \\
1960 \mathrm{~s}- \\
80 \mathrm{~s}\end{array}$ & Internal market orientation & \multirow[t]{2}{*}{$\begin{array}{l}\text { were identified, but the list was } \\
\text { continually revised }\end{array}$} & \multirow[t]{2}{*}{$\begin{array}{l}\text { Government investing in } \\
\text { priority industries }\end{array}$} & \multirow[t]{2}{*}{$\begin{array}{l}\text { The } 5^{\text {th }} \text { tax holidays; the taxation base for } \\
\text { priority projects reduced by } 30 \% \text { over } 10 \\
\text { years }\end{array}$} & \multirow[t]{2}{*}{ Poverty } & \multirow[t]{2}{*}{$\begin{array}{l}\text { Development of competitive offshore } \\
\text { software }\end{array}$} \\
\hline $\begin{array}{l}\text { India in } \\
1990 \mathrm{~s}\end{array}$ & Export orientation & & & & & \\
\hline Japan & Export orientation & $\begin{array}{l}\text { Car manufacturing, } \\
\text { knowledge-intensive } \\
\text { industries, iron and steel } \\
\text { industry }\end{array}$ & $\begin{array}{l}\text { Intensive use of advanced } \\
\text { research, development and } \\
\text { production technologies }\end{array}$ & $\begin{array}{l}\text { Applying special depreciation rates for } \\
\text { equipment }\end{array}$ & - & $\begin{array}{l}\text { Advanced management system, high level } \\
\text { of capital formation, one of the most } \\
\text { advanced economies in the world }\end{array}$ \\
\hline USA & $\begin{array}{l}\text { Strategic policy (with } \\
\text { innovation component) }\end{array}$ & High-tech industries & $\begin{array}{l}\text { Priority is given to high } \\
\text { technologies, and meeting } \\
\text { social needs }\end{array}$ & $\begin{array}{l}\text { Tax incentives, subsidizing, government } \\
\text { financing, R\&D, direct support for } \\
\text { education, creating special economic zones }\end{array}$ & - & $\begin{array}{l}\text { Advanced global economy. Limited use of } \\
\text { renewable and non-renewable natural } \\
\text { resources }\end{array}$ \\
\hline $\begin{array}{l}\text { Ireland in } \\
1980 \mathrm{~s}\end{array}$ & Industrial decentralization & $\begin{array}{l}\text { Agricultural } \\
\text { raw materials processing } \\
\text { industries }\end{array}$ & $\begin{array}{l}\text { Fiscal stabilization, } \\
\text { restructuring, welcoming } \\
\text { globalization, abandoning } \\
\text { protectionist practices }\end{array}$ & $\begin{array}{l}\text { Tax amnesties, state subsidies, } \\
\text { infrastructure development, abatements } \\
\text { given to international investors }\end{array}$ & $\begin{array}{l}\text { Foreign trade } \\
\text { deficit }\end{array}$ & $\begin{array}{l}\text { Low inflation rate, large high-tech sector } \\
\text { share in the total GDP }\end{array}$ \\
\hline Finland & $\begin{array}{l}\text { Strategic policy (with } \\
\text { innovation component) }\end{array}$ & $\begin{array}{l}\text { Clusters of information and } \\
\text { communication technologies }\end{array}$ & $\begin{array}{l}\text { Priorities in allocating limited } \\
\text { resources for R\&D; } 2 / 3 \text { of } \\
\text { research projects are financed } \\
\text { privately (Erofeeva, 2011) } \\
{[28] .}\end{array}$ & $\begin{array}{l}\text { Tax incentives, subsidizing, government } \\
\text { financing, R\&D, direct support for } \\
\text { education, venture capital funding, state } \\
\text { funding of } R \& D\end{array}$ & - & Fast industrial and economic growth \\
\hline
\end{tabular}


Source: authors' development

\section{Industrial Policy Agents}

Restructuring is based on the assessment of the industry structure optimality and on the balance of interests between the industrial process actors (Industrial Policy for National Champions, 2011) [29]. In shaping the industrial policy an agreement should be reached on development strategies for all entities that are going to implement it. The interests of all entities should be accommodated, and a compromise should be reached in sharing risks. The following four groups of actors should participate on equal terms in shaping the national industrial policy:

1. Academic community: universities, research centers, design bureaus, academic circles.

2. Government entities: the President, the federal government, regional authorities.

3. Private business and integrated business groups.

4. Civil society: business leagues, the Chamber of Commerce and Industry, lobbying organizations; non-governmental organizations, political parties, customers' associations.

Each group has its own role in shaping the industrial policy, and their roles are not very clear. It is private business, however, that plays the key part in the process, being ".... locomotive of industrial modernization and implementation of new technologies", whereas "the state is to ensure the appropriate regulatory environment and create infrastructure which will facilitate the private sector development and help businesses save costs and become more competitive" (The industrial policy as the key to ensuring competitiveness of an industrial region, 2006) [30]. It is worth pointing out that the more harmonious relations between the groups are, the more stable the national economy is (Korolev, 2008) [31].

\section{The Principles of Shaping and Implementing the Industrial Policy}

"An industrial policy implemented on different levels should consider the unique conditions of each region, competitive advantages of the country in question and the development level of its production forces. For each particular region, the industrial policy should be compatible with the region's industry development strategy, contribute to modernization of basic industries that are traditionally strong in the region, rely on the existing competitive advantages of the region and lay the groundwork for the development of knowledgeintensive technologies" (Goryacheva, 2013) [17].
The national industrial policy that consolidates efforts to increase international competitiveness while integration is going on is shaped and implemented on the following principles:(1)The national industrial policy should be unified and coordinated with the industrial policies of other countries economically integrated into the same international structure; (2)The industry of a particular state should be restructured using competitive advantages of priority knowledge-intensive productions; (3)The real economy should be made efficient and profitable by developing the infrastructure and creating a mobile resource base; (4) Equal rights of entities operating in the same economic space should be ensured when the industrial policy is implemented on a micro level; (5)The efforts of the industrial policy agents should be consolidated; (6) Results of R\&D should be transparent, collaboration in R\&D and fundamental research and joint commercialization of products are essential; (7) Mobility of labor, horizontal and vertical rotation of staff should be ensured; (8) The technical standards and regulations of countries making part of economically integrated structures should be harmonized; (9) Assessments of the industrial policy success, whether the policy is implemented on a national or an international level, should be comparable with each other; (10) All entities should be responsible for successful implementation of the industrial policy. "The proposed guiding principles for shaping and implementing the industrial policy, as well as harmonization of the national industrial policies of countries which participate in integration processes make it possible to form competitive associations capable of getting to a whole new level of industrial production and competitiveness" (Goryacheva, 2013) [17].

Structural Components. The multi-level industrial policy is structured both hierarchically and horizontally. Its individual structural components are listed in Table 2 
Table 2: Structural Components of the Industrial Policy

\begin{tabular}{|c|c|}
\hline Level & Structural Components \\
\hline 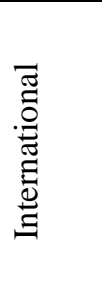 & $\begin{array}{l}\text { Scope: national economy } \\
\text { Priority approach: systematic } \\
\text { Agents: bodies that govern integrated structures, the industrial policy development commission } \\
\text { Incentive methods: implementing industrial development framework programs, targeted funding of } \\
\text { research activities } \\
\text { Outcomes: effective labor division on the level of integrated structures, raising the competitiveness of } \\
\text { national economies }\end{array}$ \\
\hline 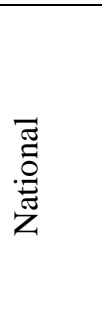 & $\begin{array}{l}\text { Scope: particular economic sectors / fields of operation, production complexes } \\
\text { Priority approach: systematic } \\
\text { Agents: academic community, private business owners, civil society, integrated business groups, the } \\
\text { Chamber of Commerce and Industry (CCI) } \\
\text { Incentive methods: federal targeted programs, project/program-tied lending, equity financing, shared or } \\
\text { joint co-financing, establishing guarantee funds, shaping innovative markets, offering lease operations } \\
\text { Outcomes: restructured production facilities, improved competitiveness of the national economy, } \\
\text { increased prosperity }\end{array}$ \\
\hline 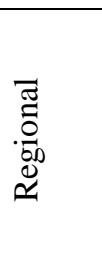 & $\begin{array}{l}\text { Scope: business units/entities } \\
\text { Priority approaches: situational, functional } \\
\text { Agents: presidential plenipotentiary envoys in Russia's regions, governor and regional representatives of } \\
\text { federal authorities, CCI } \\
\text { Incentive methods: targeted programs } \\
\text { Outcome: competitive regional clusters that ensure industry development in the region }\end{array}$ \\
\hline 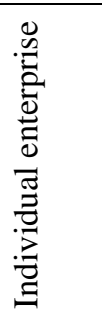 & $\begin{array}{l}\text { Scope: individual manufacturers, the company's brand portfolio } \\
\text { Priority approaches: process, function-and-structure-oriented } \\
\text { Agent: the company management } \\
\text { Incentive methods: providing soft loans to innovative projects, insuring innovations, providing assistance } \\
\text { in personnel training and retraining, providing information support for innovative activities } \\
\text { Outcomes: increased domestic and international competitiveness of the business, increased well-being of } \\
\text { employees }\end{array}$ \\
\hline
\end{tabular}

Source: authors' development

\section{The Industrial Policy Methods}

In their industrial policies, Russia and other countries use such a wide variety of methods that it is always possible to pick a good combination. The industrial policy agents' task is to find a combination which will produce the best result. The methods in question fall under the following categories:

1. Methods based on collecting and spreading information: consulting, making forecasts for the social and economic development, international monitoring of technological innovations.

2. Economic methods: ensuring financial stability, reducing budgetary gap, maintaining stable exchange rate of the national currency, reducing inflation, and maintaining external surplus of the country.

3. Methods based on providing renewable resources to market agents responsible for industrial development: labor force immigration, setting up insurance funds to insure companies against investment and export risks, providing funds for personnel training and retraining, partial financing of fundamental research and applied
R\&D, providing targeted subsidies and loans, state procurement.

4. Institutional methods: business management reforms, setting up advanced market institutes (concerns, holdings, financial industrial groups, special economic zones, associations of manufacturers and consumers), regulating industrial development.

5. Social, political and administrative methods: state control exercised through appropriate structures and their functions, interaction between authorities and private entrepreneurs. These methods define barriers for the development of manufacturing industry and the entire economy.

6. Regulatory and legislative methods serve as regulators, on the one hand, and create incentives, on the other. They lay the regulatory and legal groundwork for industrial and economic development and stipulate interaction between the industrial policy agents.

Apart from conventional methods, it is advisable to use a number of other methods including structural ones. "Structural methods ensure that the industrial sector has a well-balanced structure: they create incentives for 
making clusters or Standorts. Both clusters and Standorts create favorable framework conditions for bringing investors and labor force to certain geographic areas whose development mainly depends on the local authorities rather than the federal government. Another method that can be effectively used for choosing industrial development strategies is the foresight method. It is used when it is necessary to make a political decision on choosing priority strategic development fields for a country, a particular sector of economy, or a corporation (the decision makers take into consideration the available resource base and existing restrictions)" (Zhabin, Volkodavova \& Goryacheva, 2015; Rodrik, 2004, 2008 a, b) [18; 32-34].

\section{Discussion}

The success of a particular industrial policy is measured by the outcomes of its implementation. This approach suggests that the industrial policy is implemented on the so-called "micro" level. Knowing how successfully the policy was implemented on that level, one can predict how successful it will be on higher levels. It means that we need to create an efficient mechanism for implementing the industrial policy - a mechanism which is nowadays absent in most cases.

To this end, a graphical model matching resources with outcomes is presented, which can be used for implementing the industrial policy on the level of an individual enterprise. The model represents a chain of consecutive iterations during which the system's "input" parameters are converted to its "output" parameters (Figure 1). During the conversion one or more parameters undergo qualitative and/or quantitative changes. At any particular moment the internal state of the system is described by a set of parameter values. Studying conversion processes reveals the following chain of consecutive transformations between "inputs" and "outputs": resources system costs-activities-varies types of outcome-improved performance.

"Inputs" (elements describing the initial state of the system) are the company's resources and their characteristics.

"Outputs" are the outcomes obtained. They can be material or have the form of information or consist in social performance improvement. To ensure that the system produces the best outcomes, parameter changes should be controlled.

"Resources" are the company's resources and their characteristics which determine how successfully the company's structural units will be able to cope with the challenges presented by implementation of the company's industrial policy.

"Costs" are parameters showing how efficiently various company division units use the available resources in implementing the industrial policy.

Activities" describe and specify the work carried out by appropriate division units within the company while it is implementing its industrial policy. "Outcomes" fall into three groups: tangible, informational and administrative (related to organization and management structure). Knowing the outcomes makes it easier to improve the company's performance, make the business more competitive, improve the employees' well-being, increase the company's share in both domestic and international markets and secure its position on the market.

\section{Summary}

The national industrial policy combines the country's industrial development strategy with the mechanism for production development, productivity enhancement, making businesses and products more competitive and supporting employment. In a broader sense, it involves taking measures to promote fair competition, enhance production co-operation and specialization in the regions, and create incentives for performance improvement and introduction of new technologies. In the restricted sense, the industrial policy should support particular sectors of economy, companies and projects. It helps to change the economy structure and make the industry more competitive.

The proposed mechanism for implementing industrial policy makes companies more competitive through mastering the manufacture of high-tech products in line with the state's industrial development strategy. Manufacturing such products secures the company's stable position in domestic and international markets and improves its employees' well-being while the new integration processes are going on.

Import substitution policy, therefore, mainly consists in shaping the structure of Russia's manufacturing industry in such a way that restrictions on import of goods and technologies are differentiated. That policy stimulates the development of certain manufacturing industries to improve their competitiveness on the domestic market. It is critical for modern Russia that the import share in the domestic product cost is reduced. Reducing this share will help reduce indirect import, import penetration rate and reliance on imported components.

\section{References}

1- Polovinkin, V. N., \& Fomichev, A. B. (2014). Problems of Import Substitution in the National Economy. Expertnii Soyuzn [Expert League], Vol. 12, 34 (in Russian). Retrieved from: http://www.unionexpert .ru/index.php/zhurnal-qekspertnyj-soyuzq-osnova/ zhurnalqehkspertnihyj-soyuzq-122014g/item/655problemy-importozameschenia.

2- Wade, R. H. (2012). Return of industrial policy? International Review of Applied Economics, 26(2), 223-239. DOI: 10.1080/02692171.2011.640312. Retrieved from: https://www.scopus.com/inward/record.uri?eid=2-s2.084858162044\&doi $=10.1080 \% 2$ f02692171.2011.64031 2\&partnerID $=40 \&$ md5=52d69eceb65ddbfe54bf724539 c9f7dc.

3- Wade, R. (2010). After the Crisis: Industrial Policy and the Developmental State in Low-Income Countries Global Policy, 1(2), 150-161. DOI: 10.1111/j.1758-5899.2010.00036.x. Retrieved from https://www.scopus.com/inward/record.uri?eid=2-s2.079952928866\&doi $=10.1111 \% 2 \mathrm{fj} .1758$ - 
5899.2010.00036.x\&partnerID=40\&md5=df8ec2c54ed 2dc20f6303a0bc317826e.

4- Nathan, M., \& Overman, H. (2013). Agglomeration, clusters, and industrial policy. Oxford Review of Economic Policy, 29 (2), pp. 383-404. DOI: 10.1093/oxrep/grt019.

Retrieved from: https://www.scopus.com/inward/recor d.uri?eid=2-s2.0-

84887725341\&doi $=10.1093 \% 2$ foxrep\%2fgrt019\&part nerID $=40 \& m d 5=13 \mathrm{e} 31 \mathrm{dd} 151 \mathrm{c} 0 \mathrm{~d} 86 \mathrm{ce} 26304 \mathrm{a} 4540118 \mathrm{~b}$ 7.

5- Lazzarini, S.G. (2015). Strategizing by the government: Can industrial policy create firm-level competitive advantage? Strategic Management Journal, 36(1), 97-112. DOI: 10.1002/smj.2204. Retrieved from: https://www.scopus.com/inward/recor d.uri?eid=2-s2.0-

84918785141\&doi $=10.1002 \% 2$ fsmj. 2204\&partnerID= 40\&md5=9657acb8243dfcdfd6cf75fe5ccd484d.

6- $\quad$ Aghion, P., Cai, J., Dewatripont, M., Du, L., Harrison, A., \& Legros, P. (2015). Industrial policy and competition. American Economic Journal: Macroeconomics, 7(4), 132. DOI: $10.1257 / \mathrm{mac} .20120103$. Available at: https:// www.scopus.com/inward/record.uri?eid=2-s2.0$\underline{84944539602 \& \text { doi }=10.1257 \% 2 \mathrm{fmac} .20120103 \& \text { partne }}$ rID=40\&md5=0c245a4455b4699ec4f39988914f8044 . 7- Intarakumnerd, P. (2016). Development and Modern Industrial Policy Practice: Issues and Country Experiences. Asian-Pacific Economic Literature, 30 (2), 121-123. DOI: 10.1111/apel.12167. Retrieved from: http://apps.webofknowledge.com/full record.do?produ $\mathrm{ct}=$ WOS\&search mode $=$ GeneralSearch\&qid=11\&SID $=\mathrm{Q} 2 \mathrm{Sau} 2 \mathrm{iaBtgVdYe} 5 \mathrm{~T} 81 \&$ page $=1 \&$ doc $=13 \&$ cacheurl FromRightClick=no.

8- Yiyun, Wu, \& Xiwei, Zhu (2017). Industrial policy and economic geography: evidence from China. JOURNAL OF THE ASIA PACIFIC ECONOMY, 22(1), 173-190. DOI: $\quad 10.1080 / 13547860.2016 .1261485$. Retrieved from: http://apps.webofknowledge.com/full record.do?produ $\mathrm{ct}=$ WOS\&search mode $=$ GeneralSearch\&qid=11\&SID $=\mathrm{Q} 2$ Sau2iaBtgVdYe5T81\&page $=1 \&$ doc $=1 \&$ cacheurlF romRightClick=no.

9- The report of the Civic Chamber of the Russian Federation on industrial policy and innovations for 2007[Internet]. The Russian version is available at: http://rud.exdat.com/docs/index-634735.html.

10- Medvedev, D.A. (2015). New Reality: Russia and Global Challenges. Voprosy ekonomiki [Economic Issues], No. 10, 5-29 (in Russ).

11- El-Erian, M. A. (2010). Navigating the New Normal in Industrial Countries. Per Jakobsson Foundation Lecture, Per Jacobsson Foundation. Washington, D.C. Retrieved from: http://www.imf.or g/en/News/Articles/2015/09/28/04/53/sp101010

12- Kazantsev, N. M. (2003). Institues Providing Legal Regulation for the State's Industrial Policy (in Russ.) Retrieved from:

http://www.ptechnology.ru/Science/Science41.html. 13- Federal Law No. 488 passed on December 31, 2014, known as The Russian Federation's Industrial
Policy Act (as amended). The original Russian version is available at: http://base.garant.ru/70 833138/\#help\#ixzz3sUIdUB5B. (in Russ).

14- Tolkachev, S. A. (2014). Industrial Policy and Mainstream: Reasons for Incompatibility, Ekonomist,4, 70-80 (in Russ.).

15- Goryacheva, T. V. (2012). Shaping the RF's Industrial Policy in the Context of Deepening Economic Integration (in Russian). Innovatsionnaya deyatel'nost [Innovation Activities], 4(22), 80-90 (in Russ).

16- Goryacheva, T. V. (2013). Theoretical and Methodological Foundations for Shaping the RF's Industrial Policy in the Context of Deepening Economic Integration: Monograph, Saratov: Published by the Russian State University of Trade and Economics in Saratov, 128 (in Russ).

17- Zhabin, A. P., Volkodavova, E. V., \& Goryacheva, T. V. (2015). Multilevel Industrial Policy: Methodological Basis of System Approach to Its Formation and Implementation. Asian Social Science, 11(7), 176-182. (in Russ).

18- Volkodavova, E. V., \& Zhabin, A. P. (2016). Creating Mechanisms to Implement Import Substitution Policy for Russia's Economy, Ekonomikai predprinimatel'stvo [Economics and Business], 11.3 (76-3), 1139-1142. (in Russ).

19- Volkodavova, E. V., Zhabin, A. P., \& Yakovlev, G. I. (2016). Dichotomy of Import Substitution and Cooperation Strategies in Industry. Economic Annals-XXI, 162 (11-12), 48-52.

20- Fal'tsman, V. K. (2015). Import Substitution in the Economic Sectors of Russia. Studies on Russian Economic Development, 26(5), 452-459. DOI: $10.1134 / \mathrm{S} 1075700715050056$. Retrieved from: https://www.scopus.com/inward/record.uri?eid=2-s2.084940654719\&doi $=10.1134 \% 2 \mathrm{fS} 1075700715050056$ \&partnerID $=40 \&$ md5=932c9008a785dc56dbe8c715e6 aeddf8 .

21- Kashbrasiev, R. V., \& Stepin, A. G. (2016). Examining Russian regions from an import substitution perspective. Academy of Marketing Studies Journal, 20 (Special Issue), pp. 67-74. Retrieved from: https://www.scopus.com/inward/record.uri?eid=2-s2.0$\underline{84995569123 \& \text { partnerID=40\&md5=d69358c4a1f976f }}$ 1e287e4afa16b0f13.

22- Andrianov, K. N. (2012). Germany's Industrial Policy: the Key Aspects and Focal Points, Vestnik MGIMO-Universiteta [Annals of MGIMO - Moscow State Institute of International Relations] (in Russian), 5, 149-154 (in Russ).

23- Afanasyev, G. E. (2007). The History of Ireland, St. Petersburg: LKI Publ., 318 (in Russ).

24- Babynina, L. (2010). Flexible Integration into the EU: Classification and Chanllenges of Institutionalization.Mirovayaekonomika imezhdunarodniyeotnosheniya, 6, 31-37 (in Russ).

25- $\quad$ McMillan, C. J. (2008) The Japanese Industrial System (Translated into Russian). Moscow: Progress Publisher, 312.

26- Okimoto, D. L. (1991). Yaponskiyopytgosudarstvennogovmeshatel'stva v funktsionirovaniyerynka. Moscow: Yaponiasegodnia 
[Today's Japan], 142 pp. [possibly the abridged Russian translation of Okimoto, Daniel L. (1989) Between MITI and the Market: Japanese Industrial Policy for High Technology. Stanford: Stanford University Press, 288 pp.].

27- Erofeeva, T. P. (2011). The Place and Role of Industrial Policy in Modern Russia's Economy.Collected papers of the Free Association of Russian Economists, Vol. 102, No. 3, pp. 527-539.

28- Industrial Policy as the Basis for Ensuring Competitiveness of an Industrial Region: to the $7^{\text {th }}$ Congress of Edinaya Rossiya [Russia United]. The Government of Sverdlovsk Province. Moscow: RealMedia Publ., 2006. 231. (in Russ).

29- Industrial Policy for National Champions (2011). Falck, O., Gollier, C., \& Woessmann, L. (eds.). Cambridge, London: The MIT Press, 206.

30- Korolev, E. A. (2008). Interaction Between Government and Private Sector Agents in the European Union, Moscow: State University Publ. - Higher School of Economics, 158 pp. (in Russ).

31- Rodrik, D. (2004). Industrial Policy for the Twenty-First Century. Retrieved from: https://www.sss.ias.edu/files/pdfs/Rodrik/Research/ind ustrial-policy-twenty-first-century.pdf [accessed: 26, March 2017].

32- Rodrik, D. (2008a). Normalizing Industrial Policy. Commission on Growth and Development. Working Paper, No. 3. Washington DC, pp.1-29.

33- Rodrik, D. (2008b). Industrial Policy: Don't Ask Why, Ask How. Middle East Development. Journal 1(1), 1-29. Doi:10.1142/S1793812009000024.

[Internet].Retrieved from:

http://drodrik.scholar.harvard.edu/files/danirodrik/files/industrial-policy-dont-ask-why-askhow.pdf. 
Helix Vol. 8(2): 3237-3247

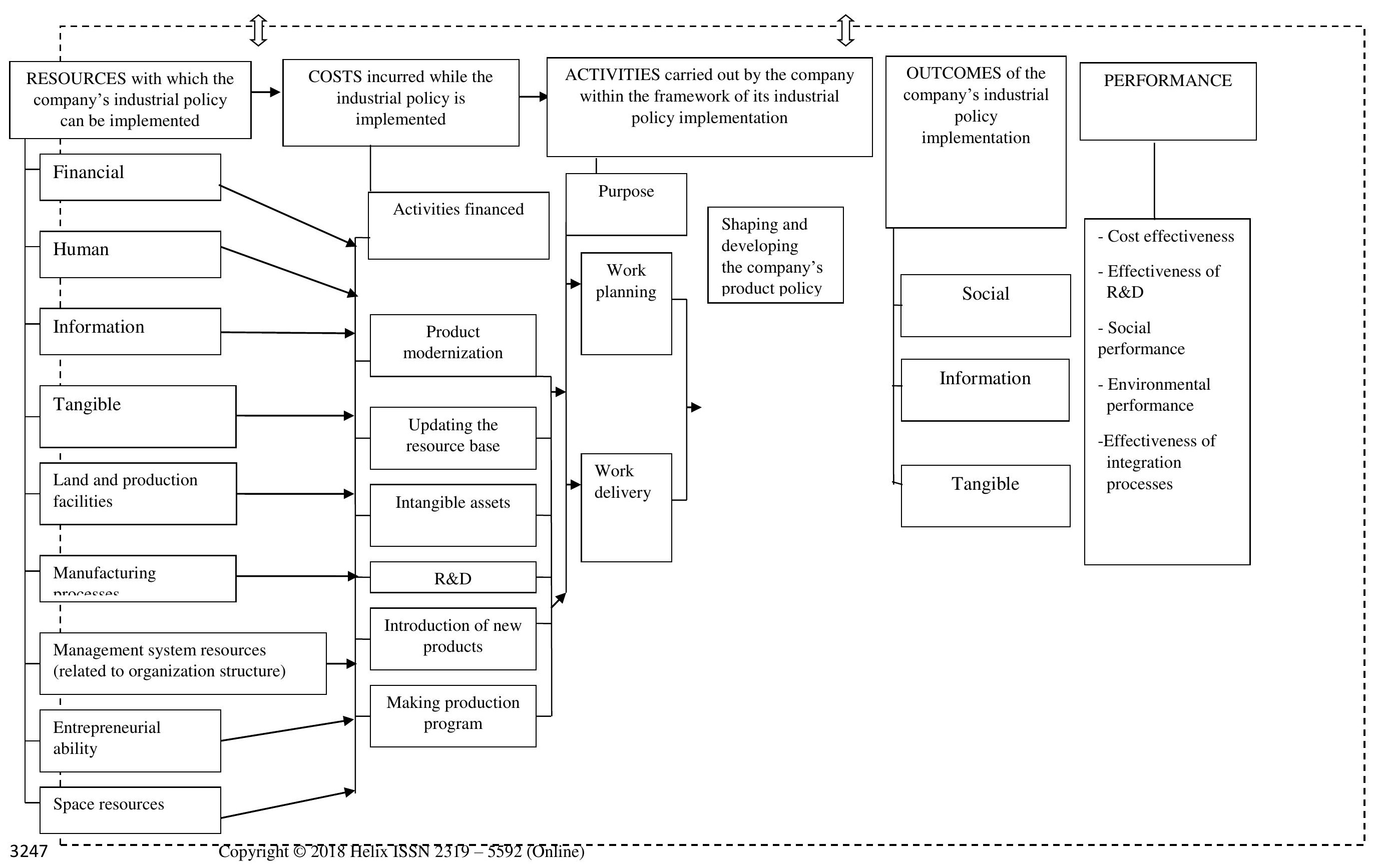

